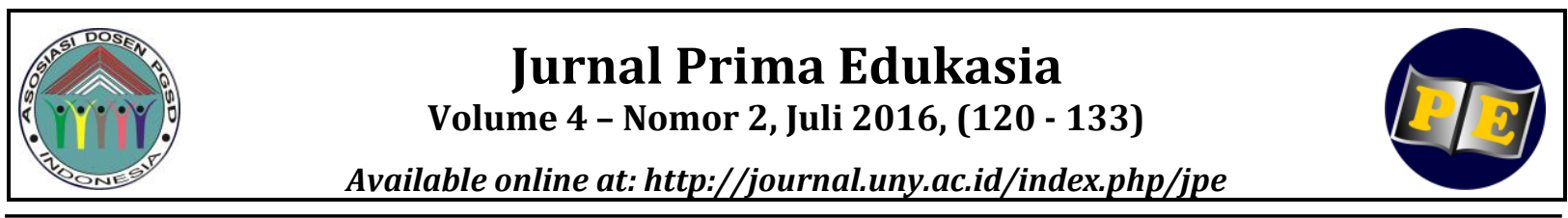

\title{
PENGEMBANGAN PERANGKAT PEMBELAJARAN UNTUK MENINGKATKAN MOTIVASI BELAJAR DAN KARAKTER BERSAHABAT SISWA KELAS IV SD
}

\author{
Diana Setyorini ${ }^{1)}$, Rita Eka Izzaty ${ }^{2)}$ \\ ${ }^{1}$ SD Negeri 74 Pagaralam, Sumatera Selatan. Jalan Pesirah Ratu Seniun Ds. Pagardin. Gunung Gare, \\ Pagar Wangi, Kec. Dempo Utara, Kota Pagar Alam, Indonesia. \\ ${ }^{2}$ Psikologi, Universitas Negeri Yogyakarta. Jalan Colombo No.1, Yogyakarta 55281, Indonesia. \\ Email: ${ }^{1}$ dianasetyorini96@yahoo.co.id, ${ }^{2}$ rita_ekaizzaty@uny.ac.id
}

\begin{abstract}
Abstrak
Penelitian ini bertujuan untuk (1) menghasilkan perangkat pembelajaran collaborative learning berbasis kearifan lokal yang layak untuk meningkatkan motivasi belajar dan karakter bersahabat siswa dan (2) mengetahui keefektifan perangkat pembelajaran collaborative learning berbasis kearifan lokal untuk meningkatkan motivasi belajar dan karakter bersahabat siswa. Penelitian ini merupakan penelitian dan pengembangan mengacu pendapat Borg dan Gall, namun desain pengembangan perangkat pembelajaran ini hanya meliputi 9 langkah, yaitu (1) penelitian pendahuluan dan pengumpulan informasi, (2) perencanaan, (3) pengembangan draft produk, (4) uji coba terbatas, (5) merevisi hasil uji coba terbatas, (6) uji coba lapangan, (7) penyempurnaan produk hasil uji coba lapangan, (8) uji coba lapangan operasional, dan (9) penyempurnaan produk akhir. Subyek penelitian adalah siswa kelas IV SD Piyungan Bantul. Hasil penilaian perangkat pembelajaran menurut ahli materi sebesar $96 \%$ untuk Silabus dan 97,30 \% untuk RPP dan menurut ahli pembelajaran sebesar 97,6\% untuk Silabus dan 97,84\% untuk RPP, sehingga perangkat pembelajaran ini layak digunakan dengan kategori valid. Berdasarkan hasil penelitian diketahui $\mathrm{p}<0,05$,yang berarti bahwa terdapat perbedaan yang signifikan terhadap motivasi belajar dan karakter bersahabat antara siswa yang mengikuti pembelajaran dengan perangkat pembelajaran collaborative learning berbasis kearifan lokal dan yang tidak menggunakan perangkat pembelajaran hasil pengembangan.
\end{abstract}

Kata Kunci: perangkat pembelajaran, collaborative learning, motivasi, karakter

\section{DEVELOPING LEARNING KITS TO ENHANCE LEARNING MOTIVATION AND FRIENDLY CHARACTER IN FOURTH GRADE ELEMENTARY SCHOOL STUDENTS}

\begin{abstract}
This study aims to (1) produce a collaborative learning kit based on local wisdom that is feasible to increase learning motivation and friendly character and (2) determine the effectiveness of the collaborative learning kit based on local wisdom to improve learning motivation and friendly character. This study is a research and development refering to the opinion of Borg and Gall, but this developing learning kit only consisting of nine steps including (1) research and information collection, (2) planning, (3) developing preliminary form of draft product, (4) preliminary field testing, (5) main product revision, (6) main field testing, (7) operational product testing, (8) operational field testing, and (9) final product revision. Subjects were fourth grade students Piyungan Bantul. The results of the assessment learning kits according to subject material expert by $96 \%$ for syllabus and $97.30 \%$ for lesson plan and learning expert by $97.6 \%$ for syllabus and $97.84 \%$ lesson plan, so that the learning kits are effective for use with a valid category. The operational field testing obtained $p<0.05$, which means that there are significant differences on motivation to learn and friendly character of the students who take the collaborative learning with learning kits based on local wisdom and those who do not use the results of the development of learning kits.
\end{abstract}

Keywords: kit learning, collaborative learning, motivation, character

How to Cite: Setyorini, D., \& Izzaty, R. (2016). Pengembangan perangkat pembelajaran untuk meningkatkan motivasi belajar dan karakter bersahabat siswa kelas IV SD. Jurnal Prima Edukasia, 4(2), 120-133. doi:http://dx.doi.org/10.21831/jpe.v4i2.8215

Permalink/DOI: http://dx.doi.org/10.21831/jpe.v4i2.8215 
Jurnal Prima Edukasia, 4 (2), Juli 2016 - 121

Diana Setyorini, Rita Eka Izzaty

\section{Pendahuluan}

Pendidikan merupakan sebuah alat untuk mewujudkan bangsa yang berkarakter. Salah satu yang berperan penting sebagai ujung tombak pendidikan adalah guru. Undang-undang Guru dan Dosen No 14 Tahun 2005 pasal 1 menyebutkan bahwa guru adalah pendidik profesional dengan tugas utama mendidik, mengajar, membimbing, mengarahkan, melatih, menilai dan mengevaluasi siswa pada pendidikan anak usia dini jalur pendidikan formal, pendidikan dasar dan pendidikan menengah. Peran guru dalam pelaksanaan pendidikan karakter di SD meliputi mendidik, mengajar, membimbing, mengarahkan, melatih, menilai, dan mengevaluasi siswa. Guru SD memegang peranan yang sangat strategis dalam membentuk karakter dan meningkatkan motivasi belajar siswa.

Pada setiap pembelajaran, guru juga harus memperhatikan motivasi belajar siswa. Peraturan Pemerintah nomor 19 tahun 2005 pasal 19 tentang Standar Nasional Pendidikan (SNP) menyebutkan bahwa proses pembelajaran pada satuan pendidikan diselenggarakan secara interaktif, inspiratif, menyenangkan, menantang, memotivasi siswa untuk berpartisipasi aktif, serta memberikan ruang yang cukup bagi prakarsa, kreativitas, dan kemandirian sesuai dengan bakat, minat, dan perkembangan fisik serta psikologis siswa. Hal ini dapat diartikan bahwa setiap guru yang mengajar di kelas, diharapkan dapat mengelola pembelajaran yang menarik dan dapat memotivasi siswa untuk dapat berpartisipasi secara aktif dalam setiap pembelajaran, sehingga motivasi dan kreativitas siswa dapat berkembang sesuai minat dan bakatnya.

Motivasi belajar merupakan faktor psikis yang bersifat non intelektual. Motivasi mempunyai peranan penting dalam proses belajar mengajar. Bagi siswa, motivasi belajar dapat menumbuhkan semangat belajar sehingga siswa terdorong untuk melakukan kegiatan belajar dengan penuh antusias. Motivasi belajar akan mengaktifkan perilaku, mengarahkan perilaku, memberikan energi terhadap perilaku belajar.

Need assessment dilakukan di kelas IV SD Piyungan Bantul pada bulan Juli 2015 terdiri atas observasi, wawancara, kajian literatur dan analisis perangkat pembelajaran yang sudah ada. Berdasarkan observasi dan wawancara dengan guru di lapangan, rata-rata sekitar 30\% dari 90 siswa kelas IV di SD Piyungan memiliki motivasi belajar yang masih rendah. Hal ini terlihat dari siswa kurang antusias dalam mengikuti pelajaran, masih ada siswa yang bermain sendiri, siswa tidak memperhatikan penjelasan guru meski ada di dalam kelas, dan siswa mengganggu teman yang sedang memperhatikan guru. Jika tidak dilakukan perbaikan, motivasi yang rendah ini, dapat menyebabkan menurunnya prestasi belajar siswa. Hal ini sejalan dengan pendapat Saeed dan Zyngier (2012, p.253), bahwa motivasi sebagai syarat dan elemen yang diperlukan dalam kegiatan belajar. Hasil penelitian menunjukan bahwa anak-anak yang terlibat langsung dalam pembelajaran dapat meningkatkan motivasi belajar mereka. Siswa lebih bersemangat menyelesaikan tugas yang diberikan, meskipun sulit.

Faktor yang mempengaruhi motivasi belajar siswa berasal dari siswa itu sendiri, baik dari dalam dirinya sendiri maupun dari luar, yaitu lingkungan sekitarnya. Dari dalam diri siswa adalah sejauh mana siswa termotivasi untuk belajar sehingga memiliki prestasi yang tinggi. Tinggi rendahnya motivasi siswa dalam belajar juga sangat dipengaruhi oleh minat siswa terhadap pembelajaran. Dari luar siswa, motivasi dipengaruhi oleh guru, orang tua dan teman sepermainan.

Selain menanamkan motivasi belajar yang kuat pada siswa, guru juga harus bisa menanamkan nilai-nilai karakter, salah satunya adalah karakter bersahabat. Arti penting bersahabat bagi siswa SD adalah bermain dalam kelompok, berinteraksi dan memiliki teman akrab atau sahabat. Namun tidak dengan siswa kelas IV SD Piyungan, berdasarkan wawancara dengan guru di lapangan, sekitar 26\% dari 90 siswa kelas IV di SD Piyungan belum sepenuhnya menunjukan karakter bersahabat dengan teman. Contohnya, siswa tidak dapat menyimak pendapat orang lain, kurang pandai berkomunikasi antar sesama teman, tidak peduli pada teman dan jika diajak berkelompok, masih memilih milih teman yang sejenis, sehingga kelompok masih bersifat homogen.

Penting bagi guru untuk menanamkan karakter bersahabat antar siswa, terutama bagi siswa kelas IV, karena merupakan awal memasuki kelas tinggi. Pada masa ini, anak-anak gemar membentuk kelompok sebaya, biasanya untuk dapat bermain dan belajar bersama. 
Jurnal Prima Edukasia, 4 (2), Juli 2016 - 122

Diana Setyorini, Rita Eka Izzaty

Sampai kira-kira umur 11 tahun, anak membutuhkan guru atau orang dewasa lainnya sebagai pembimbing.

Siswa perlu dibimbing dalam berinteraksi dengan teman satu kelas. Jangan sampai dalam satu kelas terjadi pengelompokan siswa, anak yang pandai akan selalu berteman dengan yang pandai. Siswa hendaknya bisa berteman dengan siapa saja, dan karakter bersahabat bisa tertanam sejak awal memasuki kelas IV. Sekolah merupakan salah satu sarana anak untuk membentuk karakter bersahabat. Sekolah merupakan salah satu sarana bagi anak untuk bersosialisasi.

Di kelas IV SD Piyungan, pada pembelajaran tema 5, subtema 2, Pahlawanku Kebanggaanku, pada pembelajaran 1, 2, 3, dan 6, guru masih menampilkan pahlawan dan rempahrempah daerah lain. Padahal Daerah Istimewa Yogyakarta sendiri memiliki yang tidak kalah baiknya dibanding daerah lain. Hal ini menyebabkan masih banyak siswa yang belum mengetahui kearifan lokal sendiri. Menurut Undang-undang Nomor 32 tahun 2009, tentang perlindungan dan pengelolaaan lingkungan hidup, kearifan lokal adalah nilai-nilai luhur yang berlaku dalam tata kehidupan masyarakat untuk antara lain melindungi dan mengelola hidup secara lestari. Pembelajaran yang berbasis kearifan lokal, dapat melestarikan tata nilai budaya setempat. Penerapan nilai-nilai luhur budaya dalam pendidikan merupakan suatu upaya dalam rangka mewujudkan lingkungan pendidikan yang harmoni dan berkelanjutan melalui pemanfaatan pengetahuan dan kearifan lokal dengan pendekatan kontekstual dan partisipatif (Dispora DIY, 2014,p.5).

Pembelajaran yang baik adalah pembelajaran yang terencana. Oleh karena itu, untuk melaksanakan pembelajaran yang berhasil menanamkan karakter dan meningkatkan motivasi belajar siswa, guru harus membuat perencanaan yang matang tentang langkah-langkah yang akan dilakukan selama pembelajaran sehingga pembelajaran akan menyenangkan bagi siswa. Berdasarkan hasil wawancara dengan guru kelas IV SD Piyungan, dijelaskan bahwa guru belum menyusun perangkat pembelajaran, guru hanya menyalin perangkat pembelajaran tahun sebelumnya sebagai pedoman pelaksanaan pembelajaran yang akan dilaksanakan. Hal ini dikarenakan guru tidak memiliki waktu yang cukup untuk membuat Rencana Pelaksanaan Pembelajaran (RPP). Tentu saja hal ini kurang baik, karena RPP yang tahun sebelumnya belum tentu sesuai dengan kebutuhan di SD Piyungan saat ini. Berdasarkan kajian literatur, bahwa untuk membuat perangkat pembelajaran dengan baik, haruslah sesuai dengan teori pembelajaran yang ada, sehingga di dapat perangkat pembelajaran yang sesuai dengan kebutuhan siswa.

Sebagaimana telah lama diterapkan di Jepang, collaborative learning bisa menjadi salah satu solusi model pembelajaran yang bisa menanamkan karakter dan meningkatkan motivasi belajar pada anak (Mustadi, 2014, p.22). Collaborative learning merupakan kegiatan belajar melalui kerjasama antara siswa (yang lebih mampu membantu yang kurang) untuk menyelesaikan suatu permasalahan. Dengan kata lain siswa saling belajar melalui teman sebaya. Pengalaman belajar seperti ini merupakan pengalaman berbagi pengetahuan sehingga mampu melahirkan ikatan emosional, spiritual, dan juga empati diantara siswa. Hal ini sejalan dengan hasil penelitian oleh Laal dan Ghodsi (2012, p. 486), bahwa collaborative learning memberi banyak manfaat, menghasilkan prestasi dan produktivitas yang lebih besar, lebih perhatian, memberi semangat dan membangun hubungan antar teman. Pembelajaran dengan collaborative learning, siswa yang semula tidak akrab terpaksa harus akrab dan menjalin komunikasi intensif dalam satu kelompok.

Berdasarkan penjelasan tersebut, hal yang sangat dibutuhkan dalam rangka meningkatkan motivasi belajar dan karakter bersahabat adalah perangkat pembelajaran yang menjadi acuan guru untuk mengajar. Hal ini sejalan dengan hasil penelitian dari Qodriyah \& Wangid (2015, p.177) bahwa perangkat pembelajaran terdiri atas silabus, RPP, Lembar Kegiatan Siswa (LKS) dan lembar penilaian yang dikembangkan dengan baik, efektif dan layak dapat meningkatkan karakter kejujuran dan kepedulian siswa sekolah dasar kelas II.

Penelitian ini akan mengembangkan perangkat pembelajaran collaborative learning berbasis kearifan lokal. Pembelajaran dengan collaborative learning yang berbasis kearifan lokal akan memberikan manfaat yang lebih dibandingkan dengan pembelajaran yang konvensional. Hal ini sejalan dengan pendapat Terenzini, dkk. (2001, p. 123) bahwa metode belajar aktif atau kolaboratif memberikan hasil 
yang signifikan secara statistik dan substansial lebih besar bagi siswa daripada pembelajaran yang menggunakan metode lebih tradisional.

Perangkat pembelajaran ini, diharapkan dapat mempermudah guru dalam melaksanakan proses belajar mengajar sehingga ketercapaian tujuan pembelajaran lebih maksimal. Perangkat pembelajaran untuk meningkatkan motivasi belajar dan karakter bersahabat belum dikembangkan di SD Piyungan, sehingga akan sangat bermanfaat dan dapat digunakan untuk memenuhi kebutuhan guru.

\section{Metode}

Model Pengembangan

Model pengembangan diadaptasi dari model pengembangan menurut Borg dan Gall (1983, p.775). Namun penelitian ini hanya dilaksanakan sampai pada tahap ke sembilan, yaitu: (1) penelitian pendahuluan dan pengumpulan informasi, (2) perencanaan, (3) pengembangan draft produk, (4) uji coba terbatas, (5) merevisi hasil uji coba terbatas, (6) uji coba lapangan, (7) penyempurnaan produk hasil uji coba lapangan, (8) uji coba lapangan operasional, dan (9) penyempurnaan produk akhir.

Desain Uji Coba Produk

Uji coba produk terdiri atas tiga tahap yaitu uji coba terbatas, uji coba lapangan dan uji coba lapangan operasional. Sebelum uji coba, produk perangkat pembelajaran ini divalidasi oleh ahli materi dan ahli pembelajaran kemudian direvisi. Subyek uji coba dalam penelitian ini yaitu: semua siswa kelas IV SD Piyungan, Bantul. Kelas IVA sebagai kelas uji coba terbatas, dengan subyek sebanyak 3 siswa, dan uji coba lapangan sebanyak 8 siswa. Kelas IVB sebagai kelas eksperimen dengan jumlah siswa 30 orang dan kelas IVC sebagai kelas kontrol sebanyak 30 orang.

Instrumen Pengumpulan Data

Pada penelitian ini, instrumen penelitian yang digunakan adalah penilaian silabus dan penilaian RPP, skala motivasi belajar, pedoman observasi karakter bersahabat, respon guru dan respon siswa.

\section{Teknik Analisis Data}

Data yang diperoleh terbagi menjadi dua, yaitu data sebelum dan setelah penelitian. Data sebelum pelaksanaan penelitian dalam bentuk hasil studi pustaka, wawancara, observasi dan analisis perangkat pembelajaran yang digunakan oleh guru sebagai analisis kebutuhan (need analysis) pengembangan perangkat pembelajaran. Data tersebut dianalisis menggunakan teknik analisis data kualitatif. Analisis data kualitatif pada penelitian ini berdasarkan pendapat dari Miles \& Hubberman (2014, p. 12) yang memiliki 3 tahap, yaitu, data condensation (kondensasi data), data display (penyajian data), conclusion drawing/ verification (penarikan kesimpulan/verifikasi). Data setelah penelitian berupa data kuantitatif dianalisa untuk mendapatkan perangkat pembelajaran berupa Silabus dan RPP yang layak dan efektif. Kelayakan produk yang dihasilkan di analisis dengan rumus berikut ini (Akbar, 2013, p.82):

$$
\text { nilai }=\frac{\text { skor perolehan }}{\text { skor maksimal }} \times 100 \%
$$

Kriteria kualitas perangkat pembelajaran yang dikembangkan diadaptasi dari pendapat Akbar (2013, p.155) yang dapat dilihat pada Tabel 1.

Tabel 1. Kriteria Kualitas Perangkat Pembelajaran

\begin{tabular}{cl}
\hline Nilai & \multicolumn{1}{c}{ Predikat } \\
\hline $85,01-100,00 \%$ & $\begin{array}{l}\text { Valid atau dapat digunakan } \\
\text { tanpa revisi } \\
\text { Cukup valid atau daat } \\
\text { digunakan namun perlu direvisi } \\
\text { kecil } \\
\text { Kurang valid disarankan tidak } \\
\text { gunakan karena perlu revisi } \\
\text { banyak } \\
\text { Tidak valid atau tidak boleh } \\
\text { digunakan }\end{array}$ \\
\hline
\end{tabular}

Data setelah penelitian yang dihasilkan dari skala motivasi, observasi karakter bersahabat, respon guru dan respon siswa selanjutnya dikelompokkan dengan menggunakan konversi nilai sebagai berikut (Widoyoko, 2009, p.238).

Tabel 2. Kriteria penilaian

\begin{tabular}{|c|c|c|}
\hline Interval skor & Nilai & Kategori \\
\hline $\mathrm{X}>\mathrm{Xi}+1,8 \mathrm{Sbi}$ & A & Sangat Baik \\
\hline $\begin{array}{c}\mathrm{Xi}+0,6 \times \mathrm{Sbi}<\mathrm{X} \leq \mathrm{Xi}+1,8 \\
\mathrm{Sbi}\end{array}$ & B & Baik \\
\hline $\begin{array}{c}\mathrm{Xi}-0,6 \times \mathrm{Sbi}<\mathrm{X} \leq \mathrm{Xi}+0,6 \\
\mathrm{x} \mathrm{Sbi}\end{array}$ & $\mathrm{C}$ & Cukup Baik \\
\hline $\begin{array}{c}\mathrm{Xi}-1,8 \mathrm{Sbi}<\mathrm{X} \leq \mathrm{Xi}-0,6 \mathrm{x} \\
\mathrm{Sbi} \\
\mathrm{X} \leq \mathrm{Xi}-1,8 \times \mathrm{Sbi}\end{array}$ & $\mathrm{D}$ & $\begin{array}{c}\text { Kurang } \\
\text { Baik } \\
\text { Tidak Baik }\end{array}$ \\
\hline
\end{tabular}


Jurnal Prima Edukasia, 4 (2), Juli 2016 - 124

Diana Setyorini, Rita Eka Izzaty

Keterangan:

$\mathrm{X}$ : Skor empiris (skor aktual)

$\mathrm{Xi} \quad$ : $\quad$ rerata ideal $=1 / 2($ skor maksimal + skor minimal)

Sbi : simpangan baku ideal $=1 / 6$ (skor maksimal - skor minimal)

Penilaian dikatakan memenuhi kriteria jika kategori minimal yang dicapai adalah baik.

\section{Hasil dan Pembahasan}

Studi Pendahuluan

Pada tahap studi pustaka, peneliti melakukan kajian terhadap teori-teori yang berkenaan dengan pembelajaran tematik-integratif untuk meningkatkan motivasi belajar dan karakter siswa. Kajian tersebut adalah dengan menganalisis buku dan jurnal. Kajian buku yang dianalisis adalah mengenai motivasi belajar, pendidikan karakter, teori belajar, pembelajaran tematik-integratif, dan karakter siswa kelas IV sekolah dasar. Berdasarkan hasil wawancara yang dilakukan kepada guru kelas IV di SD Piyungan, Bantul, pada bulan Juli 2015, guru belum mengembangkan perangkat pembelajaran collaborative learning berbasis kearifan lokal, yaitu silabus dan RPP. Panduan mengajar saat ini hanya berupa buku guru dan buku siswa dari pemerintah.

Dalam wawancara tersebut, guru SD Piyungan, Bantul, mengatakan bahwa guru belum membuat perangkat pembelajaran collaborative learning berbasis kearifan lokal sekaligus yang bisa meningkatkan karakter. Pernyataan guru tersebut sebagai berikut.

Ft: "Kami tidak membuat perangkat pembelajaran. Perangkat pembelajaran yang kami gunakan sekarang ini merupakan hasil dari menyalin tahun kemarin dan mengganti tahunnya saja. Kami juga hanya menggunakan buku siswa dan buku guru yang diberikan oleh pemerintah. Sebenarnya kami butuh, tapi kami tidak punya banyak waktu untuk membuat perangkat pembelajaran sendiri." (Juli 2015).

Selain wawancara, informasi juga didapat melalui observasi untuk mengetahui gambaran awal tentang karakter siswa kelas IV SD Piyungan dan proses pembelajaran beserta perangkat pembelajaran yang digunakan. Pada saat proses pembelajaran siswa sudah dikondisikan untuk belajar secara berkelompok. Namun pembagian kelompok kurang bervariasi dari segi jenis kelamin. Selain itu masih adanya kompetisi antar siswa dalam satu kelompok maupun kompetisi antar kelompok menunjukkan bahwa memang guru belum menerapkan model collaborative learning dalam pembelajaran. Adanya kompetisi inilah yang menjadi salah satu penyebab sikap egoisentris siswa dan kurang peduli terhadap teman, sehingga pembelajaran secara berkelompok kurang efektif.

Pada tahap analisis perangkat pembelajaran yang telah ada, dapat diketahui, bahwa perangkat pembelajaran yang ada belum disesuaikan dengan perkembangan dan kebutuhan siswa. Perangkat pembelajaran yang telah ada juga belum diiintegrasikan dengan nilai-nilai karakter pada siswa dan belum memasukan unsur kearifan lokal daerah setempat ke dalam perangkat pembelajaran yang telah ada.

Dari hasil hasil studi pendahuluan dapat disimpulkan bahwa guru belum membuat perangkat pembelajaran dan guru membutuhkan perangkat pembelajaran. Oleh karena itu, penelitian ini difokuskan untuk mengembangkan perangkat pembelajaran collaborative learning berbasis kearifan lokal untuk meningkatkan motivasi belajar dan karakter bersahabat siswa kelas IV SD Piyungan, Bantul.

\section{Data Hasil Validasi Ahli}

Data hasil penilaian produk berupa skor. Data hasil penilaian produk perangkat pembelajaran yang dilakukan oleh ahli materi dan ahli pembelajaran secara lengkap dapat dilihat pada Tabel 3 dan 4 .

Tabel 3. Data Hasil Penilaian Perangkat Pembelajaran Oleh Ahli Materi

\begin{tabular}{cccc}
\hline No. & $\begin{array}{c}\text { Perangkat } \\
\text { Pembelajaran }\end{array}$ & Persentase & $\begin{array}{c}\text { Kategori } \\
\text { Kelayakan }\end{array}$ \\
\hline 1 & Silabus & 96 & Valid \\
2 & RPP & 97,30 & Valid \\
\hline
\end{tabular}

Berdasarkan Tabel 3, diperoleh persentase untuk silabus sebesar 96 dan RPP sebesar 97,30. Artinya bahwa perangkat pembelajaran menurut ahli materi adalah layak digunakan setelah revisi.

Tabel 4. Data Hasil Penilaian Perangkat Pembelajaran Oleh Ahli Pembelajaran

\begin{tabular}{cccc}
\hline No. & $\begin{array}{c}\text { Perangkat } \\
\text { Pembelajaran }\end{array}$ & Persentase & $\begin{array}{c}\text { Kategori } \\
\text { Kelayakan }\end{array}$ \\
\hline 1 & Silabus & 97,6 & valid \\
2 & RPP & 97,84 & valid \\
\hline
\end{tabular}


Jurnal Prima Edukasia, 4 (2), Juli 2016 - 125

Diana Setyorini, Rita Eka Izzaty

Berdasarkan Tabel 4, diperoleh persentase untuk silabus sebesar 97,6 dan RPP sebesar 97,84 . Artinya bahwa perangkat pembelajaran menurut ahli pembelajaran adalah layak digunakan setelah revisi.

\section{Analisis Data Hasil Uji Coba Terbatas}

Uji coba terbatas dilakukan kepada siswa kelas IVA SD Piyungan, Bantul yang berjumlah 3 orang. Pemilihan subjek ini dilakukan secara acak dengan memperhatikan perbedaan kemampuan siswa, 1 orang berkemampuan tinggi, 1 orang berkemampuan sedang dan 1 orang berkemampuan rendah. Tujuan dilaksanakannya uji coba awal ini untuk mengumpulkan informasi yang dapat digunakan sebagai bahan untuk merevisi produk. Informasi yang terkumpul selama uji coba terbatas adalah hasil skala motivasi belajar siswa, observasi karakter bersahabat, respon guru dan respon siswa

Skala Motivasi Belajar Siswa

Skala motivasi belajar siswa digunakan untuk mengetahui motivasi belajar siswa sebelum dan sesudah melaksanakan pembelajaran dengan menggunakan perangkat pembelajaran collaborative learning berbasis kearifan lokal. Berikut ini data hasil motivasi belajar sebelum dan sesudah melaksanakan pembelajaran dengan menggunakan perangkat pembelajaran collaborative learning berbasis kearifan lokal.

Tabel 5. Data Hasil Skala Motivasi Belajar

Sebelum dan Sesudah Uji Coba Terbatas

\begin{tabular}{cccc}
\hline No & $\begin{array}{c}\text { Subjek } \\
\text { coba }\end{array}$ & $\begin{array}{c}\text { Skor Motivasi } \\
\text { Belajar Sebelum } \\
\text { Uji Coba } \\
\text { Terbatas }\end{array}$ & $\begin{array}{c}\text { Skor Motivasi } \\
\text { Belajar Sesudah } \\
\text { Uji Coba } \\
\text { Terbatas }\end{array}$ \\
\hline 1 & AY & 56 & 73 \\
2 & AK & 83 & 96 \\
3 & AS & 72 & 72 \\
\multicolumn{2}{c}{ Rata-rata } & 70,33 & 80,33 \\
\hline
\end{tabular}

Berdasarkan table 5, terlihat ada peningkatan motivasi belajar siswa sesudah melaksanakan pembelajaran dengan menggunakan perangkat pembelajaran collaborative learning berbasis kearifan lokal. Jika sebelum melaksanakan pembelajaran dengan perangkat pembelajaran collaborative learning berbasis kearifan lokal, rata-rata motivasi belajar siswa sebesar 70, 33, maka setelah melaksanakan pembelajaran dengan perangkat pembelajaran collaborative learning berbasis kearifan lokal, rata-rata motivasi belajar siswa sebesar 80, 33. Berikut grafik yang menggambarkan hasil peningkatan motivasi belajar.

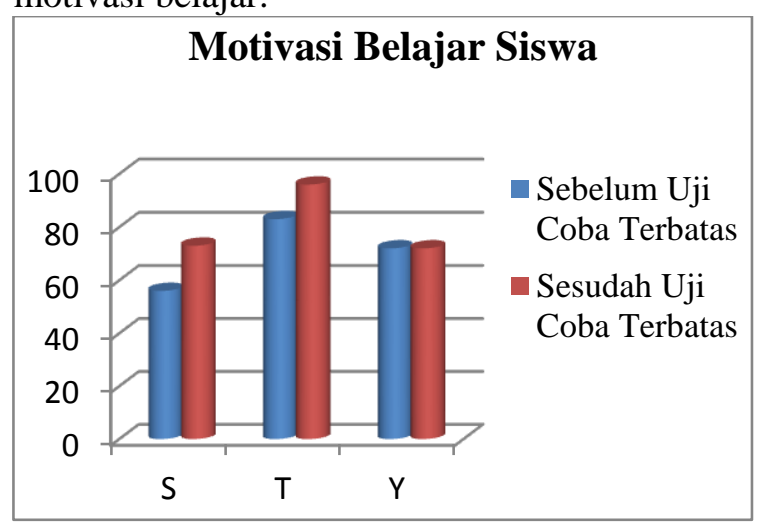

Gambar 1. Grafik Data Hasil Motivasi Belajar Siswa Sebelum dan Sesudah Uji Coba Terbatas

Berdasarkan gambar 1 di atas, motivasi belajar sesudah uji coba terbatas grafik berwarna merah lebih tinggi di banding motivasi belajar sebelum uji coba terbatas. Hal ini berarti ada peningkatan motivasi belajar siswa setelah melaksanakan pembelajaran dengan menggunakan perangkat pembelajaran collaborative learning berbasis kearifan lokal.

\section{Observasi Karakter Bersahabat}

Observasi karakter bersahabat dilakukan pada saat siswa melakukan pembelajaran dengan menggunakan perangkat pembelajaran collaborative learning berbasis kearifan lokal. Terdapat perbedaan hasil observasi karakter bersahabat siswa sebelum dan sesudah menggunakan perangkat pembelajaran collaborative learning berbasis kearifan lokal. Berikut hasil observasi karakter bersahabat sebelum dan sesudah menggunakan perangkat pembelajaran collaborative learning berbasis kearifan lokal.

Tabel 6. Data Hasil Observasi Karakter Bersahabat Sebelum dan Sesudah Uji Coba Terbatas

\begin{tabular}{cccc}
\hline No & $\begin{array}{c}\text { Subjek } \\
\text { coba }\end{array}$ & $\begin{array}{c}\text { Skor Karakter } \\
\text { bersahabat } \\
\text { Sebelum Uji } \\
\text { Coba Terbatas }\end{array}$ & $\begin{array}{c}\text { Skor Karakter } \\
\text { bersahabat } \\
\text { Sesudah Uji } \\
\text { Coba Terbatas }\end{array}$ \\
\hline 1 & $\mathrm{~S}$ & 19 & 21 \\
2 & $\mathrm{~T}$ & 18 & 21 \\
3 & $\mathrm{Y}$ & 17 & 22 \\
Rata-rata & 18 & 21,33 \\
\hline
\end{tabular}

Pada Tabel 6 terlihat perbedaan karakter bersahabat siswa sebelum mengikuti pembelajaran dengan menggunakan perangkat pembel- 
Jurnal Prima Edukasia, 4 (2), Juli 2016 - 126

Diana Setyorini, Rita Eka Izzaty

ajaran collaborative learning berbasis kearifan lokal. Sebelum menggunakan perangkat pembelajaran collaborative learning berbasis kearifan lokal, karakter bersahabat siswa rata-rata bernilai 18 dengan kategori baik. Setelah mengikuti pembelajaran dengan menggunakan perangkat pembelajaran collaborative learning berbasis kearifan lokal rata-rata karakter bersahabat siswa adalah 21, 33 dengan kategori sangat baik.

Berikut digambarkan grafik perbedaan karakter bersahabat sebelum dan sesudah mengikuti pembelajaran dengan menggunakan perangkat pembelajaran collaborative learning berbasis kearifan lokal.

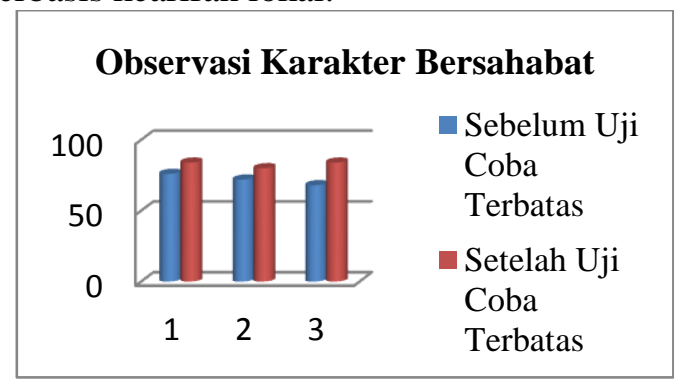

Gambar 2. Grafik Hasil Observasi Karakter Bersahabat Sebelum dan Sesudah Uji Coba Terbatas

Berdasarkan Gambar 2, terlihat karakter siswa setelah mengikuti pembelajaran dengan menggunakan perangkat pembelajaran collaborative learning berbasis kearifan lokal lebih tinggi dibandingkan sebelum mengikuti pembelajaran dengan menggunakan perangkat pembelajaran collaborative learning berbasis kearifan lokal. Dapat disimpulkan bahwa ada perbedaan hasil observasi karakter bersahabat sebelum dan sesudah menggunakan perangkat pembelajaran collaborative learning berbasis kearifan lokal.

\section{Respon Guru}

Respon guru terhadap penggunaan perangkat pembelajaran collaborative learning ber-basis kearifan lokal dapat dilihat pada Tabel 7.
Tabel 7. Data Hasil Respon Guru

\begin{tabular}{clccc}
\hline No & Subvariabel & Jumlah & Skor & Kategori \\
\hline 1 & $\begin{array}{l}\text { Kesan terhadap } \\
\text { perangkat } \\
\text { pembelajaran } \\
\text { Manfaat }\end{array}$ & 2 & 9 & Baik \\
2 & $\begin{array}{l}\text { perangkat } \\
\text { pembelajaran } \\
\text { Keefektifan } \\
\text { perangkat } \\
\text { pembelajaran } \\
\text { Jumlah }\end{array}$ & 1 & 4 & Baik \\
\hline
\end{tabular}

Dari Tabel 7, respon guru terhadap perangkat pembelajaran adalah baik, hal ini dilihat dari perolehan nilai yang diberikan oleh guru. Pada aspek kesan terhadap perangkat pembelajaran memperoleh nilai 9 dengan kategori baik, pada aspek keefektifan perangkat pembelajaran memperoleh skor sebanyak 16 dengan nilai dengan kategori baik, dan pada aspek manfaat penggunaan perangkat pembelajaran memperoleh nilai 4 dengan kategori baik. Respon guru secara keseluruhan terhadap pelaksanaan pembelajaran dengan menggunakan perangkat pembelajaran collaborative learning berbasis kearifan lokal sudah baik. Berikut ini grafik yang menggambarkan respon guru terhadap pelaksanaan perangkat pembelajaran dengan menggunakan perangkat pembelajaran collaborative learning berbasis kearifan lokal.

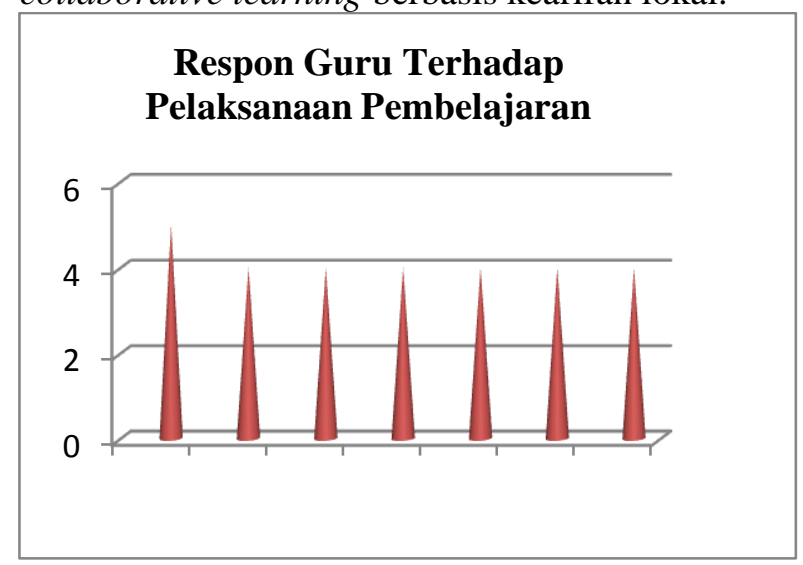

Gambar 3. Grafik Hasil Respon Guru Setelah Uji Coba Terbatas

Berdasarkan Gambar 3, terlihat respon yang diberikan guru terhadap penggunaan perangkat pembelajaran collaborative learning berbasis kearifan lokal berada di atas rata-rata, yaitu $82,85 \%$. 
Jurnal Prima Edukasia, 4 (2), Juli 2016 - 127

Diana Setyorini, Rita Eka Izzaty

Respon Siswa

Respon siswa terhadap pelaksanaan pembelajaran dengan menggunakan perangkat pembelajaran collaborative learning berbasis kearifan lokal dapat dilihat pada Tabel 8 .

Tabel 8. Data Hasil Respon Siswa

\begin{tabular}{cccc}
\hline No & Subjek & Skor & Kategori \\
\hline 1 & $\mathrm{~S}$ & 20 & Baik \\
2 & $\mathrm{~T}$ & 21 & Sangat Baik \\
3 & $\mathrm{Y}$ & 20 & Baik \\
& Rata-rata & 20,3 & Baik \\
\hline
\end{tabular}

Berdasarkan Tabel 8, skala respon dari 3 siswa peserta uji coba terbatas diperoleh ratarata skor 20,3 dengan presentase $81,33 \%$, yang berarti bahwa lebih dari $75 \%$ respon siswa terhadap pelaksanaan pembelajaran dengan menggunakan perangkat pembelajaran collaborative learning berbasis kearifan lokal ini sudah baik. Hal ini juga dapat dilihat dari tanggapan atau komentar anak terhadap pembelajaran yang telah dilaksanakan, antara lain siswa merasa lebih mudah memahami materi, senang dalam belajar, dan siswa berani mengeluarkan pendapat. Berikut grafik hasil respon siswa terhadap pelaksanaan pembelajaran menggunakan perangkat pembelajaran collaborative learning berbasis kearifan lokal.

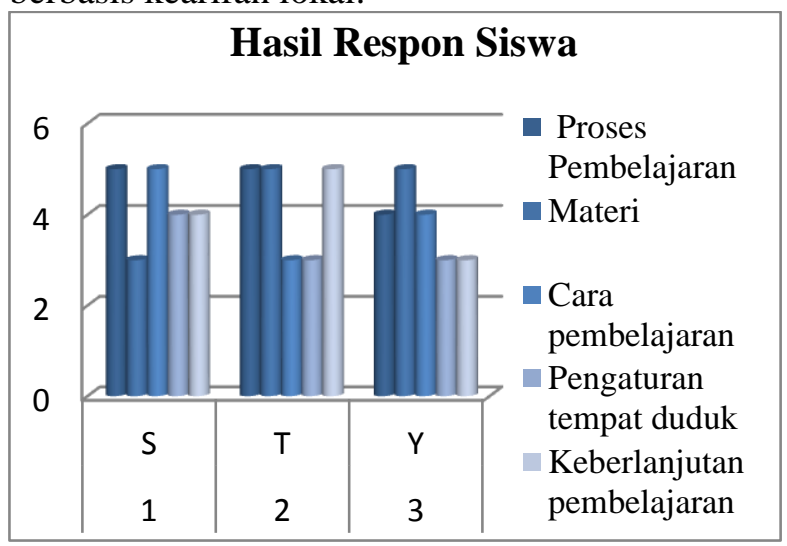

Gambar 4. Grafik Data Hasil Respon Siswa Setelah Uji Coba Terbatas

Berdasarkan Gambar 4, terlihat respon yang diberikan siswa terhadap pelaksanaan pembelajaran dengan menggunakan perangkat pembelajaran collaborative learning berbasis kearifan lokal berada di atas rata-rata.

\section{Analisis Data Hasil Uji Coba Lapangan}

Pelaksanaan uji coba lapangan dilaksanakan di SD Piyungan pada bulan November 2015. Siswa yang dijadikan sebagai uji coba lapangan yaitu kelas IVA sebanyak 8 siswa yang kesemuanya dipilih secara acak. Pemilihan subjek uji coba dilakukan secara acak dengan memperhatikan perbedaan kemampuan siswa, yaitu kemampuan tinggi 3 siswa, kemampuan sedang 3 siswa, dan kemampuan rendah 2 anak. Tujuan dilaksanakan uji coba lapangan adalah untuk mengimplementasikan produk hasil revisi dan evaluasi berdasarkan hasil uji coba terbatas. Informasi yang diperoleh dalam uji coba lapangan terkumpul adalah motivasi belajar siswa, observasi karakter bersahabat, respon guru dan respon siswa. Analisis data secara lengkap dari masing-masing data tersebut adalah sebagai berikut.

\section{Motivasi Belajar Siswa}

Motivasi belajar siswa pada uji coba lapangan terlihat meningkat sesudah melaksanakan pembelajaran dengan menggunakan perangkat pembelajaran collaborative learning berbasis kearifan lokal dibandingkan sebelum menggunakan perangkat pembelajaran collaborative learning berbasis kearifan lokal. Berikut data hasil motivasi belajar siswa sebelum uji coba lapangan dan sesudah uji coba lapangan.

Tabel 9. Data Hasil Motivasi Belajar Sebelum dan Sesudah Uji Coba Lapangan

\begin{tabular}{cccc}
\hline No & $\begin{array}{c}\text { Subjek } \\
\text { coba }\end{array}$ & $\begin{array}{c}\text { Skor Motivasi } \\
\text { Belajar Sebelum } \\
\text { Uji Coba lapangan }\end{array}$ & $\begin{array}{c}\text { Skor Motivasi } \\
\text { Belajar Sesudah Uji } \\
\text { Coba Lapangan }\end{array}$ \\
\hline 1 & AY & 74 & 79 \\
2 & AK & 69 & 75 \\
3 & AS & 68 & 70 \\
4 & FA & 74 & 74 \\
5 & GC & 74 & 76 \\
6 & MO & 81 & 81 \\
7 & MM & 66 & 97 \\
8 & NP & 60 & 79 \\
Rata-rata & 70,75 & 78,875 \\
\hline
\end{tabular}

Berdasarkan Tabel 9, ada peningkatan motivasi belajar pada siswa sebagai subjek uji coba lapangan. Sebelum melaksanakan pembelajaran dengan menggunakan perangkat pembelajaran collaborative learning berbasis kearifan lokal, rata-rata motivasi belajar pada siswa kelas IVA sebesar 70,75. Sesudah melaksanakan pembelajaran dengan menggunakan perangkat pembelajaran collaborative learning berbasis kearifan lokal, rata-rata motivasi belajar pada siswa kelas IVA sebesar 78, 875. Berikut grafik yang menggambarkan peningkatan motivasi belajar siswa pada uji coba lapangan. 
Jurnal Prima Edukasia, 4 (2), Juli 2016 - 128

Diana Setyorini, Rita Eka Izzaty

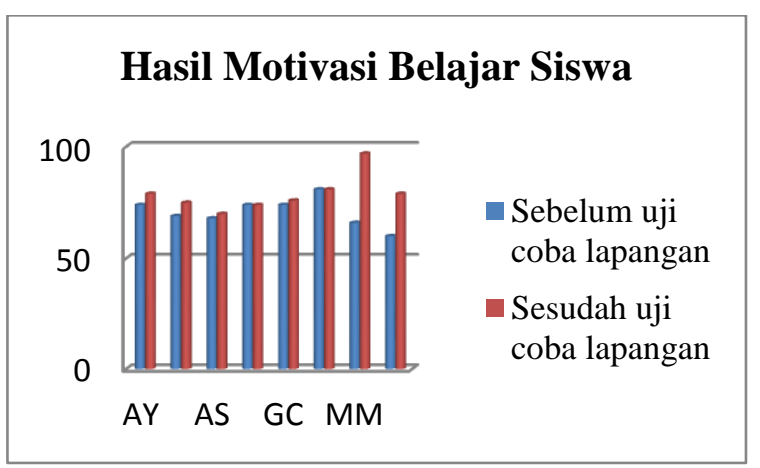

Gambar 5. Grafik Data Hasil Motivasi Belajar

Siswa Sebelum dan Sesudah Uji Coba Lapangan

Dari Gambar 5, terlihat peningkatan motivasi belajar siswa setelah melaksanakan pembelajaran dengan menggunakan perangkat pembelajaran collaborative learning berbasis kearifan lokal yang ditunjukan grafik warna merah. Grafik berwarna biru menggambarkan motivasi belajar sebelum melaksanakan pembelajaran dengan menggunakan perangkat pembelajaran collaborative learning berbasis kearifan lokal.

Observasi Karakter Bersahabat

Pada pelaksanaan uji coba lapangan, siswa yang di observasi karakter bersahabatnya sebanyak 8 orang. Terdapat perbedaan hasil karakter bersahabat pada siswa sebelum melaksanakan pembelajaran dengan menggunakan perangkat pembelajaran collaborative learning berbasis kearifan lokal dan sesudah menggunakan perangkat pembelajaran collaborative learning berbasis kearifan lokal. Data Hasil observasi karakter bersahabat pada uji coba lapangan adalah sebagai berikut.

Tabel 10. Data Hasil Observasi Karakter Bersahabat Sebelum dan Sesudah Uji Coba Lapangan

\begin{tabular}{cccc}
\hline No & $\begin{array}{c}\text { Subjek } \\
\text { coba }\end{array}$ & $\begin{array}{c}\text { Skor Karakter } \\
\text { Bersahabat } \\
\text { Sebelum Uji } \\
\text { Coba Terbatas }\end{array}$ & $\begin{array}{c}\text { Skor Karakter } \\
\text { Bersahabat } \\
\text { Sesudah Uji } \\
\text { Coba Terbatas }\end{array}$ \\
\hline 1 & AY & 17 & 20 \\
2 & AK & 19 & 20 \\
3 & AS & 17 & 21 \\
4 & FA & 18 & 18 \\
5 & GC & 17 & 18 \\
6 & MO & 18 & 20 \\
7 & MM & 17 & 20 \\
8 & NP & 19 & 21 \\
\multicolumn{2}{r}{ Rata-rata } & 17,75 & 20 \\
\hline
\end{tabular}

Berdasarkan Tabel 10, terlihat peningkatan karakter bersahabat pada siswa sebagai subjek uji coba lapangan. Sebelum melaksanakan pembelajaran dengan menggunakan perangkat pembelajaran collaborative learning berbasis kearifan lokal, rata-rata karakter bersahabat pada siswa kelas IVA sebesar 17, 75. Sesudah melaksanakan pembelajaran dengan menggunakan perangkat pembelajaran collaborative learning berbasis kearifan lokal, rata-rata karakter bersahabat pada siswa kelas IVA sebesar 20 . Berikut grafik yang menggambarkan peningkatan karakter bersahabat pada uji coba lapangan.

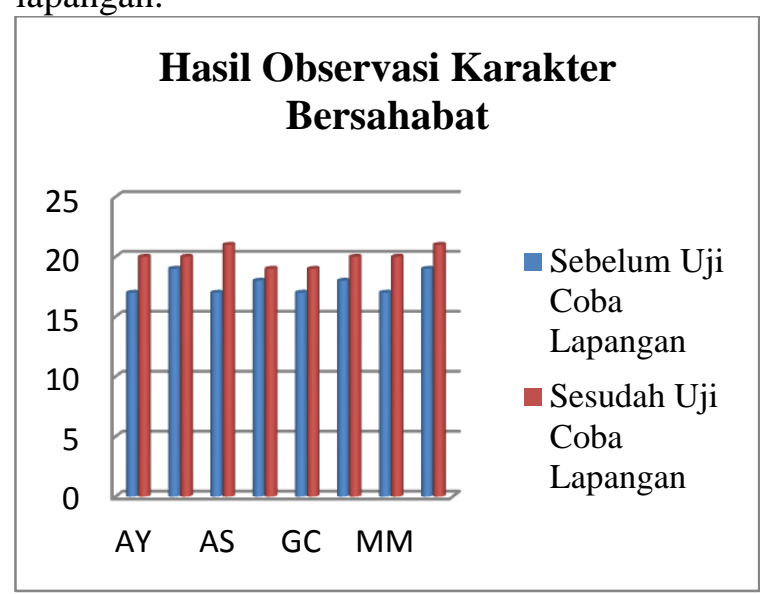

Gambar 6. Grafik Data Hasil Observasi karakter Bersahabat Setelah Uji Coba Lapangan

Berdasarkan Gambar 6, terlihat peningkatan karakter bersahabat siswa kelas IVA SD Piyungan sebagai subjek uji coba lapangan. Grafik warna merah menggambarkan hasil karakter bersahabat siswa setelah melaksanakan pembelajaran dengan menggunakan perangkat pembelajaran collaborative learning berbasis kearifan lokal lebih tinggi dibandingkan grafik warna biru yang merupakan karakter bersahabat sebelum melaksanakan pembelajaran dengan menggunakan perangkat pembelajaran collaborative learning berbasis kearifan lokal.

\section{Respon Guru}

Respon guru terhadap penggunaan perangkat pembelajaran collaborative learning berbasis kearifan lokal dapat dilihat pada Tabel 11. 
Jurnal Prima Edukasia, 4 (2), Juli 2016 - 129

Diana Setyorini, Rita Eka Izzaty

Tabel 11. Data Hasil Respon Guru

\begin{tabular}{|c|c|c|c|c|}
\hline No & Subvariabel & Jumlah & Nilai & Ket \\
\hline 1 & $\begin{array}{l}\text { Kesan terhadap } \\
\text { perangkat } \\
\text { pembelajaran }\end{array}$ & 2 & 10 & $\begin{array}{c}\text { Sangat } \\
\text { Baik }\end{array}$ \\
\hline 2 & $\begin{array}{l}\text { Manfaat } \\
\text { perangkat } \\
\text { pembelajaran }\end{array}$ & 4 & 16 & Baik \\
\hline 3 & $\begin{array}{l}\text { Keefektifan } \\
\text { perangkat } \\
\text { pembelajaran }\end{array}$ & 1 & 4 & Baik \\
\hline & Jumlah & & 30 & Baik \\
\hline
\end{tabular}

Respon guru adalah baik, hal ini dilihat dari perolehan nilai yang diberikan oleh guru. Pada aspek kesan terhadap perangkat pembelajaran memperoleh nilai 10 dengan kategori sangat baik, pada aspek keefektifan perangkat pembelajaran memperoleh nilai 16 kategori baik dan pada aspek manfaat penggunaan perangkat pembelajaran memperoleh nilai 4 dengan kategori baik. Berikut adalah grafik yang menggambar respon guru terhadap pelaksanaan perangkat pembelajaran collaborative learning berbasis kearifan lokal.

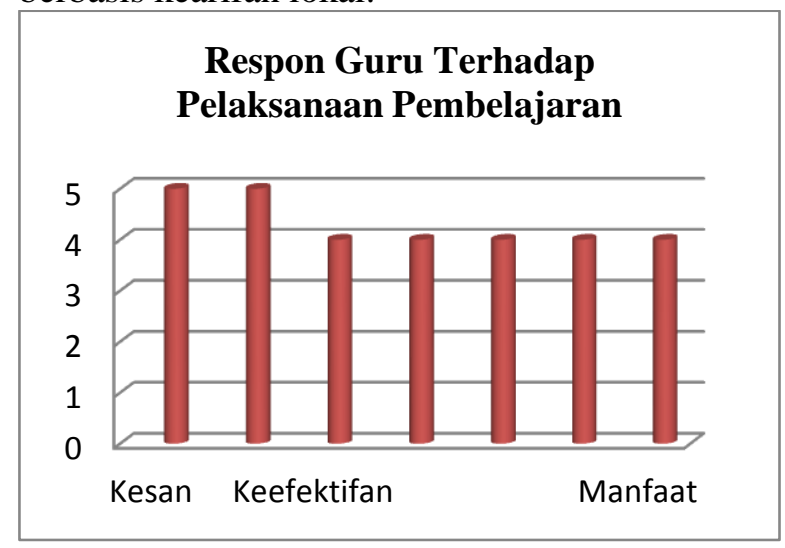

Gambar 7. Grafik Data Hasil Respon Guru Setelah Uji Coba Lapangan

Berdasarkan Gambar 7, terlihat respon yang diberikan guru terhadap penggunaan perangkat pembelajaran collaborative learning berbasis kearifan lokal berada di atas rata-rata.

\section{Respon Siswa}

Respon siswa terhadap pelaksanaan pembelajaran dengan menggunakan perangkat pembelajaran collaborative learning berbasis kearifan lokal dapat dilihat pada Tabel 12.
Tabel 12. Data Hasil Respon Siswa

\begin{tabular}{cccc}
\hline No & Subjek & Skor & Kategori \\
\hline 1 & AY & 20 & Baik \\
2 & AK & 21 & Sangat Baik \\
3 & AS & 20 & Baik \\
4 & FA & 23 & Sangat Baik \\
5 & GC & 21 & Sangat Baik \\
6 & MO & 21 & Sangat Baik \\
7 & MM & 23 & Sangat Baik \\
8 & NP & 21 & Sangat Baik \\
\multicolumn{2}{c}{ Rata-rata } & 21,25 & Sangat Baik \\
\hline
\end{tabular}

Berdasarkan Tabel 12, skala respon dari 8 siswa peserta uji coba terbatas diperoleh rerata sebesar 21, 25 yang berarti bahwa lebih dari $75 \%$ respon siswa terhadap pelaksanaan pembelajaran dengan menggunakan perangkat pembelajaran collaborative learning berbasis kearifan lokal ini sudah sangat baik. Berikut grafik hasil respon siswa terhadap pelaksanaan pembelajaran menggunakan perangkat pembelajaran collaborative learning berbasis kearifan lokal.

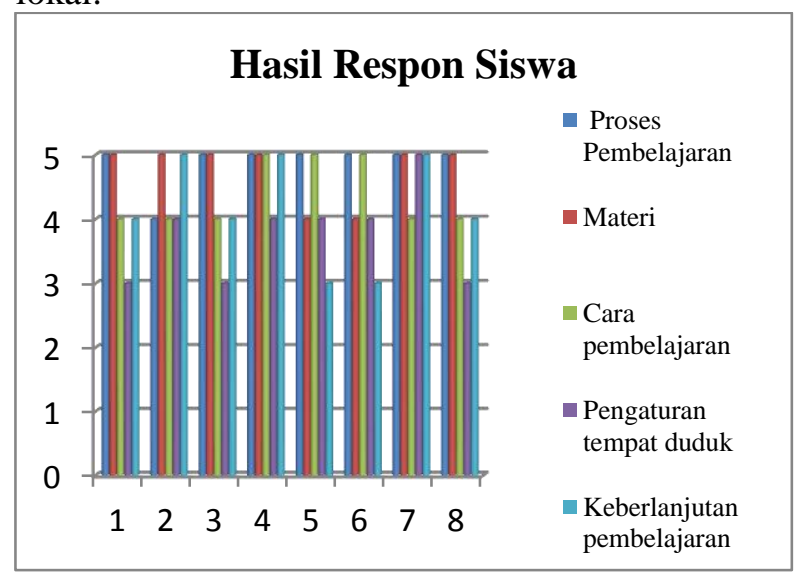

Gambar 8. Grafik Data Hasil Respon Siswa Setelah Uji Coba Lapangan

Berdasarkan Gambar 8, terlihat respon yang diberikan siswa terhadap pelaksanaan pembelajaran dengan menggunakan perangkat pembelajaran collaborative learning berbasis kearifan lokal berada di atas rata-rata.

Data Hasil Uji Coba Lapangan Operasional

\section{Motivasi Belajar Siswa}

Motivasi belajar siswa pada uji coba lapangan operasional mendapatkan hasil yang sangat baik. Terdapat perbedaan hasil motivasi belajar pada siswa sebelum dan sesudah melaksanakan pembelajaran dengan menggunakan perangkat pembelajaran collaborative learning berbasis kearifan lokal. Data hasil motivasi 
Jurnal Prima Edukasia, 4 (2), Juli 2016 - 130

Diana Setyorini, Rita Eka Izzaty

belajar sesudah uji coba lapangan operasional dapat dilihat pada tabel berikut.

Tabel 13. Data Skala Motivasi Kelas Eksperimen

\begin{tabular}{cccc}
\hline No & Interval Skor & Kategori & $\begin{array}{c}\text { Jumlah } \\
\text { Siswa }\end{array}$ \\
\hline 1 & $\mathrm{X}>83,94$ & Sangat Baik & 20 \\
2 & $67,98<\mathrm{X} \leq 83,94$ & Baik & 10 \\
3 & $52,02<\mathrm{X} \leq 67,98$ & Cukup Baik & 0 \\
4 & $36,06<\mathrm{X} \leq 52,02$ & Kurang Baik & 0 \\
5 & $\mathrm{X} \leq 36,06$ & Tidak Baik & 0 \\
& Jumlah & & 30 \\
\hline
\end{tabular}

Berikut grafik yang menggambarkan peningkatan motivasi belajar pada siswa kelas IVB sebagai kelas eksperimen.

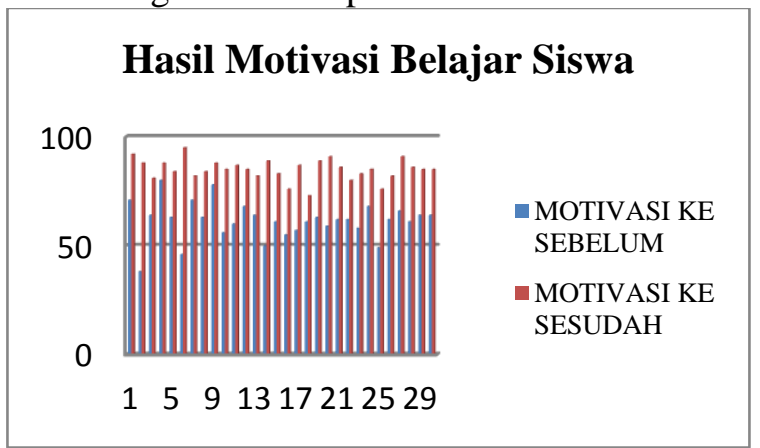

Gambar 9. Grafik Data Hasil Motivasi Belajar Uji Coba Lapangan Operasional

Berdasarkan Gambar 9, terlihat peningkatan motivasi belajar siswa kelas IVB sebagai kelas eksperimen. Sebelum uji coba lapangan operasional, rata-rata motivasi belajar siswa sebesar 61, 46 dan sesudah ujicoba lapangan operasional menggunakan perangkat pembelajaran collaborative learning berbasis kearifan lokal, rata-rata motivasi belajar siswa mengalami kenaikan menjadi 84,93.

\section{Observasi Karakter Bersahabat}

Uji coba lapangan operasional dilaksanakan di kelas IVB sebagai kelas eksperimen. Terdapat perbedaan hasil karakter bersahabat pada siswa sebelum dan sesudah melaksanakan pembelajaran dengan menggunakan perangkat pembelajaran collaborative learning berbasis kearifan lokal. Data hasil karakter bersahabat sesudah uji coba lapangan operasional dapat dilihat pada Tabel 14.
Tabel. 14. Data Hasil Observasi karakter Bersahabat

\begin{tabular}{cccc}
\hline No & Interval Skor & Kategori & $\begin{array}{c}\text { Jumlah } \\
\text { Siswa }\end{array}$ \\
\hline 1 & $\mathrm{X}>20,94$ & Sangat Baik & 27 \\
2 & $16,98<\mathrm{X} \leq 20,94$ & Baik & 3 \\
3 & $13,02<\mathrm{X} \leq 16,98$ & Cukup Baik & 0 \\
4 & $9,06<\mathrm{X} \leq 13,02$ & Kurang Baik & 0 \\
5 & $\mathrm{X} \leq 9,06$ & Tidak Baik & \\
& Jumlah & & 30 \\
\hline
\end{tabular}

Berikut grafik yang menggambarkan peningkatan karakter bersahabat pada siswa kelas IVB sebagai kelas eksperimen.

\section{Karakter Bersahabat pada Uji Coba Lapangan Operasional}

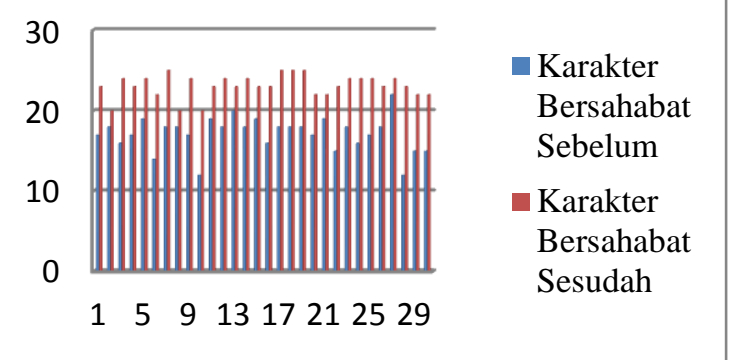

Gambar 10. Grafik Data Hasil Observasi Karakter Bersahabat Uji Coba Lapangan Operasional

Berdasarkan gambar 10, terlihat peningkatan karakter bersahabat siswa kelas IVB sebagai kelas eksperimen. Sebelum uji coba lapangan operasional, rata-rata karakter bersahabat siswa sebesar 17,13 dan sesudah uji coba lapangan operasional menggunakan perangkat pembelajaran collaborative learning berbasis kearifan lokal, rata-rata karakter bersahabat siswa mengalami kenaikan menjadi 23, 1 .

\section{Respon Guru}

Respon guru terhadap penggunaan perangkat pembelajaran collaborative learning berbasis kearifan lokal terdapat pada Tabel 15.

Tabel 15. Data Hasil Respon Guru

\begin{tabular}{clccc}
\hline No & \multicolumn{1}{c}{ Subvariabel } & Jumlah & Nilai & Ket \\
\hline 1 & $\begin{array}{l}\text { Kesan terhadap pe- } \\
\text { rangkat pembelajaran }\end{array}$ & 2 & 9 & $\begin{array}{c}\text { Sangat } \\
\text { Baik }\end{array}$ \\
2 & $\begin{array}{l}\text { Manfaat perangkat } \\
\text { pembelajaran }\end{array}$ & 4 & 17 & $\begin{array}{c}\text { Sangat } \\
\text { Baik }\end{array}$ \\
3 & $\begin{array}{l}\text { Keefektifan perangkat } \\
\text { pembelajaran }\end{array}$ & 1 & 4 & $\begin{array}{c}\text { Baik } \\
\text { Jumlah }\end{array}$ \\
& & 30 & $\begin{array}{c}\text { Sangat } \\
\text { Baik }\end{array}$ \\
\hline
\end{tabular}


Jurnal Prima Edukasia, 4 (2), Juli 2016 - 131

Diana Setyorini, Rita Eka Izzaty

Respon guru adalah sangat baik. Hal ini dilihat dari perolehan nilai yang diberikan oleh guru. Pada aspek kesan terhadap perangkat pembelajaran memperoleh nilai 9 dengan kategori sangat baik, pada aspek keefektifan perangkat pembelajaran memperoleh nilai 17 dengan kategori baik dan pada aspek manfaat penggunaan perangkat pembelajaran memperoleh nilai 4 dengan kategori baik. Berikut ini grafik yang menggambarkan respon guru terhadap pelaksanaan perangkat pembelajaran collaborative learning berbasis kearifan lokal.

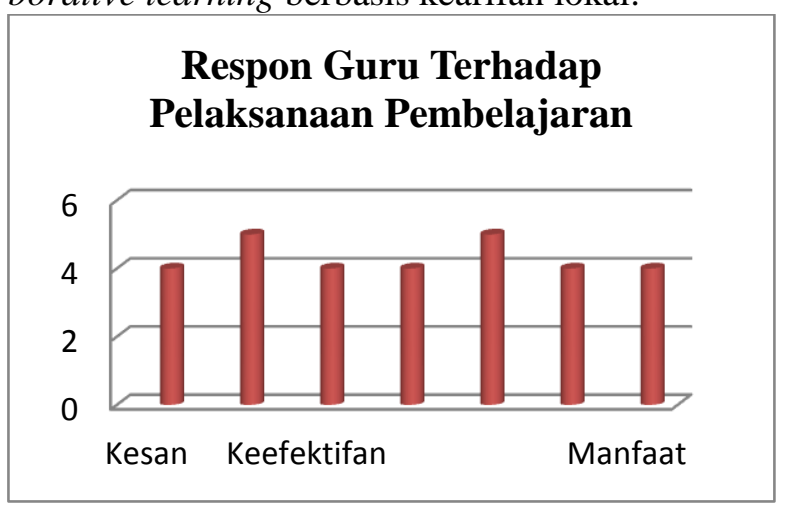

Gambar 11.Grafik Data Hasil Respon Guru

Setelah Uji Coba Lapangan Operasional

Berdasarkan Gambar 11, terlihat respon guru sudah di atas rata-rata. Respon guru terhadap penggunaan perangkat pembelajaran collaborative learning berbasis kearifan lokal memperoleh nilai sebesar 30 dengan kategori sangat baik.

Respon Siswa

Respon siswa terhadap pelaksanaan pembelajaran dengan menggunakan perangkat pembelajaran collaborative learning berbasis kearifan lokal dapat dilihat pada Tabel 16.

Tabel 16. Data Hasil Respon Siswa

\begin{tabular}{cccc}
\hline No & Interval Skor & Kategori & $\begin{array}{c}\text { Jumlah } \\
\text { Siswa }\end{array}$ \\
\hline 1 & $\mathrm{X}>20,94$ & Sangat Baik & 27 \\
2 & $16,98<\mathrm{X} \leq 20,94$ & Baik & 3 \\
3 & $13,02<\mathrm{X} \leq 16,98$ & Cukup Baik & 0 \\
4 & $9,06<\mathrm{X} \leq 13,02$ & Kurang Baik & 0 \\
5 & $\mathrm{X} \leq 9,06$ & Tidak Baik & 0 \\
& Jumlah & & 30 \\
\hline
\end{tabular}

Berdasarkan data hasil respon dari 30 siswa peserta uji coba lapangan operasional diperoleh sebanyak 27 siswa memberikan respon sangat baik, yang berarti bahwa respon siswa terhadap pelaksanaan pembelajaran dengan menggunakan perangkat pembelajaran collaborative learning berbasis kearifan lokal ini sangat baik. Berikut ini grafik yang menggambarkan respon siswa terhadap pelaksanaan pembelajaran dengan menggunakan perangkat pembelajaran collaborative learning berbasis kearifan lokal.

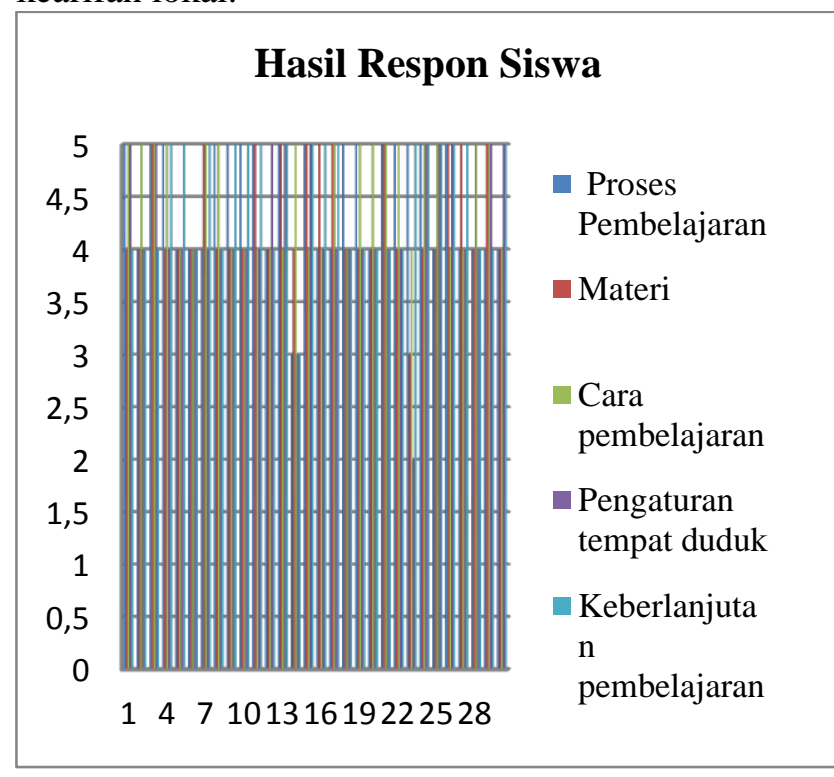

Gambar 12. Grafik Data Hasil Respon Siswa Uji Coba Lapangan Operasional

Berdasarkan Gambar 12, terlihat bahwa siswa sudah memberikan respon yang sangat baik terhadap pelaksanaan pembelajaran dengan menggunakan perangkat pembelajaran collaborative learning berbasis kearifan lokal.

Pembahasan

Berdasarkan hasil uji coba lapangan operasional, perangkat pembelajaran ini dapat meningkatkan motivasi belajar siswa. Siswa termotivasi untuk belajar bersama, saling berbagi pengetahuan, tanpa ada rasa berkompetisi. Hal ini sesuai dengan pendapat dari Cicek dan Tok (2014, p.227, bahwa pembelajaran yang direncanakan dapat memberikan harapan yang positif bagi siswa. Temuan dalam uji coba lapangan operasional, perangkat pembelajaran collaborative learning ini dapat meningkatkan motivasi belajar siswa, terlihat dari meningkatnya keinginan siswa untuk belajar, ketertarikan siswa terhadap proses pembelajaran dan keinginan siswa untuk berprestasi. Faktor lain yang terlihat adalah meningkatnya dorongan motivasi belajar dari teman, guru serta orang tua, meningkatnya harapan orang tua dan siswa menerima hadiah dari orang tua akan prestasi 
Jurnal Prima Edukasia, 4 (2), Juli 2016 - 132

Diana Setyorini, Rita Eka Izzaty

yang sudah di raihnya. Hal ini sesuai dengan pendapat Clayon, Blumberg dan Auld (2010, p.351) bahwa motivasi dan strategi yang terencana dalam pembelajaran dapat mempengaruhi hasil akademik siswa.

Perangkat pembelajaran ini juga dapat meningkatkan karakter bersahabat siswa. Rencana pelaksanaan pembelajaran yang baik tidak hanya mempengaruhi guru, namun juga siswa. Hal ini sesuai dengan pendapat Tyagi (2014, p. 14), bahwa“... for developing a student active teaching approach that relies on promising syllabus, conceptual quizzes, peer interaction, self-reflection through an after class feedback form. Hal ini berarti bahwa salah satu cara untuk mengaktifkan siswa belajar adalah tergantung pada silabus, konsep pembelajaran yang jelas, interaksi antar siswa dan refleksi setelah pembelajaran. Silabus dan RPP dalam perangkat pembelajaran ini menggunakan model collaborative learning, yang dapat membangun karakter bersahabat siswa dalam belajar secara berkelompok. Meningkatnya karakter bersahabat dapat terlihat dari adanya interaksi dengan teman di kelas, dapat memberikan pendapat orang lain, dapat bekerja sama dalam kelompok, dapat berkomunikasi dengan bahasa yang santun dan lebih peduli dengan sesama. Rancangan belajar dengan berkolaborasi memungkinkan siswa untuk saling berkomunikasi, saling berbagi pengetahuan sehingga meningkatkan karakter bersahabat diantara siswa. Hal ini sesuai dalam Pengembangan Pendidikan Budaya dan Karakter Bangsa (Kemendiknas, 2010, p. 10) yang menyebutkan bahwa karakter bersahabat/komunikatif yaitu tindakan yang memperlihatkan rasa senang berbicara, bergaul, dan bekerja sama dengan orang lain. Oleh karena itu, perangkat pembelajaran yang dikembangkan dapat meningkatkan karakter bersahabat siswa.

\section{Simpulan dan Saran}

Berdasarkan hasil penelitian dan pembahasan, maka dapat diambil kesimpulan bahwa produk perangkat pembelajaran untuk meningkatkan motivasi belajar dan karakter bersahabat dinilai layak menurut ahli materi dan ahli pembelajaran. Berdasarkan hasil penilaian oleh ahli, silabus hasil pengembangan memperoleh hasil kategori layak untuk digunakan, karena sudah sesuai dengan permendikbud No 65 tahun 2013 tentang standar proses, yaitu memuat identitas sekolah, kompetensi inti, kompetensi dasar, memuat tema, materi pokok, proses pembelajaran, penilaian, alokasi waktu dan sumber belajar.

Silabus ini merupakan silabus untuk pembelajaran subtema Pahlawanku Kebanggaanku. Mata pelajaran yang dikembangkan dalam perangkat pembelajaran ini meliputi Bahasa Indonesia, Matematika, Ilmu Pengetahuan Sosial (IPS), Ilmu Pengetahuan Alam (IPA), Pendidikan Kewarganegaraan (PPKn), Seni Budaya dan Prakarya (SBdP), dan Pendidikan Jasmani dan Olahraga Kesehatan (PJOK). Kegiatan pembelajaran dalam silabus ini didasarkan pada peningkatan motivasi belajar dan karakter bersahabat.

Berdasarkan hasil penilaian ahli materi dan ahli pembelajaran, RPP yang dikembangkan dalam penelitian layak untuk digunakan dalam pembelajaran, karena disusun sesuai dengan permendikbud No 103 tahun 2013 tentang pembelajaran pada pendidikan dasar dan menengah, yaitu memuat $\mathrm{KI}$ dan $\mathrm{KD}$, berpusat pada siswa, berbasis konteks, berorientasi kekinian, mengembangkan kemandirian belajar, memberikan umpan balik dan tindak lanjut pembelajaran, memiliki keterkaitan antar kompetensi serta memanfaatkan teknologi dan komunikasi.

RPP yang dikembangkan pada perangkat pembelajaran diintegrasikan dengan peningkatan motivasi belajar dan karakter bersahabat. Pemilihan metode pengajaran disesuaikan dengan peningkatan karakter. Pendekatan yang digunakan dalam perangkat pembelajaran adalah scientific approach sesuai Kurikulum 2013. Kegiatan pembelajaran disusun untuk 6 kali pertemuan, kemudian diakhiri dengan tes hasil belajar tematik.

Berdasarkan kajian akhir tersebut dapat dikatakan bahwa perangkat pembelajaran hasil pengembangan produk ini merupakan produk yang telah layak untuk digunakan dalam pembelajaran di kelas. Karakteristik lain dari perangkat pembelajaran dengan subtema Pahlawanku Kebanggaanku ini mempunyai beberapa keunggulan. Keunggulan perangkat pembelajaran hasil pengembangan yaitu (1) berisi perangkat-perangkat yang kesemuanya mengandung unsur-unsur karakter bersahabat sehingga peningkatan karakter dalam pembelajaran dapat berjalan dengan komprehensif. (2) Perangkat pembelajaran ini sesuai dengan 
Jurnal Prima Edukasia, 4 (2), Juli 2016 - 133

Diana Setyorini, Rita Eka Izzaty

pendekatan saintifik yang dikembangkan dalam Kurikulum 2013.

Pengembangan perangkat pembelajaran untuk meningkatkan motivasi belajar dan karakter bersahabat siswa kelas IV SD sudah diuji kelayakan dan keefektifannya, maka disarankan kepada guru: (1) menggunakan perangkat ini sebagai alternatif pedoman pelaksanaan pembelajaran yang dapat meningkatkan motivasi belajar dan karakter bersahabat; (2) menggunakan produk perangkat pembelajaran ini dengan menyesuaikan karakter siswa dan lingkungan yang ada di sekitar sekolah.

\section{Daftar Pustaka}

Akbar, S. (2013). Instrumen perangkat pembelajaran. Bandung: PT Remaja Rosdakarya.

Borg, W.R., \& Gall, M.D. (1983). Educational research: an introduction, fourth edition. New York: Pearson education Inc.

Cicek, V., \&Tok, H. (2014). Effective use of lesson plans to enhance education in u.s. and turkish kindergarten thru 12th grade public school system: a comparative study. International Academic Conference, Istanbul. 13 April 2014, 9th. Pg. 227-238.

Clayton,K., Blumberg, F., \& Auld, D.P. (2010). The relationship between motivation, learning strategies and choice of environment whether traditional or including an online component. British Journal of Educational Technology. Vol. 41 No. 3 2010, 349-364.

Kemendiknas. (2010). Bahan pelatihan pengembangan budaya dan karakter bangsa. Jakarta: Kemendiknas.

Laal, M \& Ghodsi, S.M. (2012). Befenits of collaborative learning. Procedia-social and behavioral sciences,31, p.486-490.

Menteri Pendidikan dan Kebudayaan. (2014). Peraturan Menteri Pendidikan dan Kebudayaan Nomor 103, Tahun 2014, tentang Pembelajaran pada pendidikan dasar dan pendidikan menengah.
Menteri Pendidikan dan Kebudayaan. (2013). Peraturan Menteri Pendidikan dan Kebudayaan Nomor 65, Tahun 2013, tentang Standar proses pendidikan dasar dan menengah.

Miles, M.B., Hubberman, A.M., \& Saldana, J. (2014). Qualitative data analysis a methods sourcebook edition 3.Los Angeles: Sage

Mustadi, A. (2014). http://pps.uny. ac.id/sites/pps.uny.ac.id/files/Prosiding. SEMNAS.DIKDAS.pdf. Prosiding, Maret.

Terenzini, P. T. dkk. (2001). Collaborative learning vs. lecture/discussion: students'reported learning gains. Journal of Engineering Education. Januari 2001. Pg. 123-130.

Qodriyah, S., \& Wangid, M. (2015). pengembangan SSP tematik integratif untuk membangun karakter kejujuran dan kepedulian siswa SD kelas II. Jurnal Prima Edukasia, 3(2), 177 189.

doi:http://dx.doi.org/10.21831/jpe.v3i2. $\underline{7222}$

Saeed, S \& Zyngier, D. (2012). How motivation influences student engagement:a qualitative case study. Journal of Education and Learning; Vol. 1, No. 2, 2012, 252-267.

Tim Pengembang Pendidikan berbasis budaya. (2014). Pedoman pelaksanaan pendidikan berbasis budaya. Jogjakarta: Dispora.

Tyagi, P. (2014). Teaching a course with active learning approaches and training other teachers about deep learning stretegies. International Journal for Innovation Education and Research, vol.2-12, 2014.pg 14-23

Widoyoko, E. P. (2009). Evaluasi program pembelajaran panduan praktis bagi pendidik dan calon pendidik. Yogyakarta: Pustaka Pelajar. 